\title{
Virus antibody levels and delayed hypersensitivity in rheumatoid arthritis
}

\author{
PAUL E. PHILLIPS, JACK WAXMAN, * YASHAR HIRSHAUT, \\ AND MARK H. KAPLAN† \\ From the Departments of Medicine, The Hospital for Special Surgery, the Clinical Immunology Service, \\ Memorial-Sloan Kettering Cancer Center, and Cornell University Medical College, New York
}

\begin{abstract}
Phillips, P. E., Waxman, J., Hirshaut, Y., and Kaplan, M. H. (1976). Annals of the Rheumatic Diseases, 35, 152-154. Virus antibody levels and delayed hypersensitivity in rheumatoid arthritis. Epstein-Barr virus and cytomegalovirus antibody levels were not higher in patients with rheumatoid arthritis compared to matched controls. Delayed hypersensitivity, measured by skin test reactivity, was depressed in rheumatoid arthritis. There was no correlation between virus antibody titres and delayed hypersensitivity.
\end{abstract}

The hypothesis that rheumatoid arthritis (RA) is caused by an infectious agent is widely accepted. However, attempts to implicate specific agents, whether by isolation or serology, have been unsuccessful (Phillips, 1976). Cellular immunity has not previously been studied in conjunction with humoral immunity to viruses. We report here a negative serological study in RA of antibodies to two subgroup $B$ herpesviruses, Epstein-Barr virus (EBV) and cytomegalovirus (CMV). No correlation was found between either virus antibody level and delayed hypersensitivity.

\section{Patients and methods}

Thirty-three patients with classical RA (Ropes and others, 1958) were matched for age (mean 55.7 years, range 22-74) and sex ( 27 females, 6 males) with each of two control groups. The other disease controls were hospitalized patients: 18 degenerative joint disease, 5 herniated nucleus pulposus, 7 miscellaneous orthopaedic problems (trauma, ganglion, bursitis), and 3 infections. The normal controls were blood donors.

Sera were stored at $-20^{\circ} \mathrm{C}$ and coded before testing for EBV antibody by indirect immunofluorescence (Hirshaut and others, 1970) and CMV antibody by microcomplement fixation (Armstrong and others, 1971). Titres were expressed as the $\log _{2}$ of the reciprocal of the highest positive serum dilution.

Delayed hypersensitivity was measured by intradermal testing with 5 antigens (tuberculin, mumps, streptokinasestreptodornase, trichophyton, and candida) as described previously (Waxman and others, 1973). Induration was measured in mm at 48 hours, and the sum of these measurements defined as the skin test index.

Student's ' $t$ ' test was used to measure the significance of differences between means, and Pearson's correlation coefficient for relationships between two variables (Croxton, 1959).

\section{Results}

The incidence and distribution of EBV antibody titres were similar in RA and both control groups. Two RA patients and one normal control lacked antibody. Mean EBV antibody was similar in RA to both control groups (Table), although the other disease controls were significantly higher than the normal controls.

The incidence and distribution of CMV antibody was also similar in RA and the other disease control group; the normal controls were not tested. Eight RA patients and 6 controls lacked antibody. Mean CMV antibody was similar in both groups (Table). Additional unmatched classical RA patients were also tested for CMV antibody; the mean titre (3.96) for the entire group of $55 \mathrm{RA}$ patients was similar to the matched subgroup and still not different from the controls.

Delayed hypersensitivity, as measured by skin testing, was significantly reduced in RA patients compared to the other disease controls (Table); the normal controls were not tested.

Accepted for publication October 16, 1975.

* Present address: Department of Internal Medicine, Ochsner Clinic, 1514 Jefferson Highway, New Orleans, LA 70121, U.S.A.

+ Present address: Nassau County Medical Center, East Meadow, NY 11554, U.S.A.

Correspondence to Dr. P. E. Phillips, Hospital for Special Surgery, 535 East 70th Street, New York, NY 10021, U.S.A. 
Table Mean levels of Epstein-Barr virus (EBV) and cytomegalovirus (CMV) antibodies and skin test index in $R A$ and controls

\begin{tabular}{|c|c|c|c|}
\hline & \multirow{2}{*}{$\begin{array}{l}\text { Rheumatoid } \\
\text { arthritis }\end{array}$} & \multicolumn{2}{|l|}{ Controls } \\
\hline & & $\begin{array}{l}\text { Other } \\
\text { disease }\end{array}$ & Normal \\
\hline \multicolumn{4}{|l|}{ EBV antibody $\left(\log _{2}\right)$} \\
\hline $\begin{array}{l}\text { Mean } \\
\text { SD } \\
\text { Range }\end{array}$ & $\begin{array}{l}8 \cdot 33 \\
2 \cdot 44 \\
\text { Neg-13.3 }\end{array}$ & $\begin{array}{l}9 \cdot 06^{*} \\
1 \cdot 56 \\
7 \cdot 3-13 \cdot 3\end{array}$ & $\begin{array}{l}7 \cdot 89 \\
1 \cdot 64 \\
\mathrm{Neg}-11 \cdot 3\end{array}$ \\
\hline \multicolumn{4}{|l|}{ CMV antibody $\left(\log _{2}\right)$} \\
\hline $\begin{array}{l}\text { Mean } \\
\text { SD } \\
\text { Range }\end{array}$ & $\begin{array}{l}4 \cdot 21 \\
2 \cdot 11 \\
\text { Neg-8 }\end{array}$ & $\begin{array}{l}4 \cdot 32 \\
1 \cdot 94 \\
\mathrm{Neg}-6\end{array}$ & NT \\
\hline \multicolumn{4}{|l|}{ Skin test index } \\
\hline $\begin{array}{l}\text { Mean } \\
\text { SD } \\
\text { Range }\end{array}$ & $\begin{array}{l}7 \cdot 3 \dagger \\
10 \cdot 5 \\
0-30\end{array}$ & $\begin{array}{l}23 \cdot 2 \\
18 \cdot 7 \\
0-57\end{array}$ & NT \\
\hline
\end{tabular}

- Significantly higher than normal controls, $P<0.005$.

+ Significantly lower than controls, $P<0.01$.

NT = not tested.

Significant correlations were not found between age, sex, or skin test index and either virus antibody titre, nor between the two virus antibodies themselves. The only significant correlation was an inverse one between skin test index and age in the RA group $(r=-0.38 ; \mathrm{P}<0.05)$.

\section{Discussion}

The normal levels of EBV and CMV antibody do not support an aetiological role for either of these viruses in RA. Other virus antibodies have also been studied in RA, but no consistent increase in titre or incidence has emerged (Phillips, 1976). The role of viruses in RA thus remains speculative.

The decreased skin reactivity in RA has been described previously, and these patients were part of that study (Waxman and others, 1973). The decreasing skin reactivity with older age found here no doubt reflects the decreasing reactivity associated with longer disease duration found there. Treatment did not affect skin reactivity; aspirin and corticosteroid (maximum daily dose $10 \mathrm{mg}$ prednisone) usage were similar in both high and low reactivity RA groups.
It is probable that the low reactivity found overall in RA is not specific for this disease. Rather it may indicate 'preoccupation' of the lymphocyte response with a foreign antigen. Other examples of this may be the decreased skin reactivity found during acute viral infections, lepromatous leprosy, and sarcoidosis (Waxman and others, 1973).

Correlations between humoral immunity to viruses and cellular immunity as measured by skin testing have not previously been sought in RA. However, in lepromatous leprosy where skin reactivity is reduced, high EBV antibodies were found, while in the tuberculoid form where skin reactivity is intact or enhanced, EBV antibody was normal (Papageorgiou and others, 1971). Those authors postulated that the decreased cellular immunity in the lepromatous type allowed enhanced EBV replication, thus stimulating more antibody production. By extrapolation, they hypothesized a similar reason for the high EBV antibodies in sarcoidosis, where skin reactivity is also reduced, and further that high EBV antibodies would be found in other diseases with impaired cellular immunity (Papageorgiou and others, 1971). In this study no such relationship was found, suggesting the lack of any such general linkage between the two types of immune response, at least to the various microbial antigens used here.

It might be expected that increased specific humoral immunity with either absent or increased specific cellular immunity would be found to the postulated infectious agent causing RA (Phillips, 1976). Studies of both types of immune response to the same microbial agent have not been reported. EBV and CMV skin test antigens are not available, thus assessment of specific cellular immunity to these agents would require in vitro testing. However, the lack of increased antibodies to EBV and CMV in the presence of a depressed cellular response to other microbial, including virus, antigens suggests that no specific abnormalities of the cellular response to EBV and CMV would be found.

Supported in part by grants from the New York Chapter of the Arthritis Foundation, the John A. Hartford Foundation, NIAMDD Special Fellowship Award no. 1 FO3 AM54059-01, the New York Cancer Research Institute, and the U.S. P.H.S. NIH CA-08748.

\section{References}

Armstrong, D., Balakrishnan, S., Steger, L., Yu, Y., And Stenzel, K. H. (1971) Arch. int. Med., 127, 111 (Cytomegalovirus infections with viremia following renal transplantation)

Croxron, F. E. (1959) In 'Elementary Statistics with Applications in Medicine and the Biological Sciences', pp. 112, 228, 267, 312. Dover Publications, New York

Hirshaut, Y., Glade, P., Vieira, L. O., Ainbender, E., Dvorak, B., and SiltzBach, L. E. (1970) New Engl. J. Med., 283, 502 (Sarcoidosis, another disease associated with evidence of herpes-like virus infection)

Papageorgiou, P. S., Sorokin, C., Kouzoutzakoglou, K., and Glade, P. R. (1971) Nature, 231, 47 (Herpes-like Epstein-Barr virus in leprosy) 
PHILlirs, P. E. (1976) 'Virus infections and rheumatic disease: possible models for the pathogenesis of rheumatoid arthritis', in 'Topics in Rheumatology', ed. G. R. V. Hughes. Heinemann, London (in press)

Ropes, M. W., BenneTt, G. A., CobB, S., JACOX, R., AND Jessar, R. A. (1958) Bull. rheum. Dis., 9, 175 (Revision of diagnostic criteria for rheumatoid arthritis)

WAXMAN, J., Lockshin, M. D., SCHNAPP, J. J., AND Doneson, I. N. (1973) Arthr. and Rheum., 16, 499 (Cellular immunity in the rheumatic diseases. I. Rheumatoid arthritis) 